\title{
Accidental injuries in the dissecting room
}

\author{
ROMERO-REVERON, R.* \\ Departamento de Anatomía Humana, Universidad Central de Venezuela - UCV, Los Chaguaramos, Ciudad \\ Universitaria, 1060, Caracas, Venezuela \\ *E-mail: rafal636@yahoo.es
}

\begin{abstract}
Introduction: Dissection of human cadavers is a core component of human anatomy teaching and learning at many medical schools but it is coupled with the risk of injury. Materials and Methods: A retrospective cohort analysis of accidental injuries in the dissecting room was undertaken at the Human Anatomy Department J.M. Vargas medical school during 2009-2012. Results: A total of 10 accidental injuries, were recorded, all minor. Eight $(80 \%)$ injuries were from scalpel blade, other two injuries were through formatin fluids splash on the face. Discussion: Results emphasize the importance of scalpel blade safe handling techniques to reduce the risks of accidental injury.
\end{abstract}

Keywords: accidental injury, anatomy teaching, dissecting room, human anatomy, scalpel blade injury.

\section{Introduction}

Human anatomy has historically been a cornerstone in medical education. Human anatomy is the discipline in which medical students learn the basic language of medicine, learn to develop understanding through experimentation and develop skills in solving problems in a three-dimensional space (ARRÁEZ-AYBAR, SÁNCHEZ-MONTESINOS, MIRAPEIX et al., 2010).

The dissection of human cadavers is a core component of anatomy teaching at many medical schools (KORF, WICHT, SNIPES et al., 2008).

For many medical students dissection of human cadavers is their first experience to handling human tissue with surgical instruments and therefore this is inherent occupational hazards associated with this activity (ELIZONDO-OMAÑA, GUZMAN-LOPEZ and GARCIA, 2005).

Among other benefits, this exercise typically introduces the students to surgical instruments that need to be handed in a safe and coordinated manner. However, this activity is coupled with risk of accidental injury. Only a few studies have analyzed the frequency, nature, and mechanism of injuries incurred by medical students in the dissecting room (CORNWALL and STRINGER, 2008; CORNWALL, DAVIES and LEES, 2013; ROMERO, 2011).

The present study is a review of accidental injuries in the dissecting room occurring during a 4 year period at the Human Anatomy Department J.M. Vargas medical school in Caracas, Venezuela. The teaching of anatomy has changed substantially over the past two decades. A new generation of medical students have benefited from a wide array of novel anatomical imaging techniques including $3 \mathrm{D}$ reconstructions. Nevertheless, dissection of human cadavers is still a fundamental method for the teaching of this discipline (LEMPP, 2005; TURNEY, 2007).

Although cadaver dissection is now considered safe compared with the previous period of time (SHOJA, BENNINGER,
AGUTTER et al., 2013), there is still a risk of injury to those who dissect. Special care must be taken to reduce risks to a minimum. Infectious pathogens in cadavers that present particular risks include hepatitis B and C, Mycobacterium tuberculosis, the AIDS virus HIV, and prions that cause transmissible spongiform encephalopathies such as Creutzfeldt-Jakob disease and Gerstmann-Straussler-Scheinker syndrome. (BROWN, GIBBS JUNIOR, GAJDUSEK et al., 1986). It is necessary for the medical students to realize the incidence and nature of accidental injuries in the dissecting room in order to make an accurate assessment of the risks associated with this duty.

\section{Materials and Methods}

The dissecting room at the Human Anatomy Department J.M. Vargas Medical School in Central University of Venezuela is an anatomy teaching resource for medical students. Dissection of human cadavers forms part of the undergraduate training for medical students. A retrospective cohort analysis of accidental injuries in the dissecting room was made for the period 2009-2012.

At the beginning of the first dissection class for each year for every course, members of the staff of Human Anatomy Department of J.M. Vargas Medical School gave practical demonstrations that included how to safely mount, remove, and dispose scalpel blades was shown.

In the dissecting room, all medical students wear disposable gloves and long sleeved laboratory coats during these sessions.

Standard dissection equipment included scalpel handles and disposable blades, dissection scissors and forceps.

No major changes in dissection equipment or practice were introduced during the 4 years study period. Thus of the 18 first year medical students average per cadaver, no more than 4 medical students are dissecting at any given time. Non-dissecting students remained adjacent to the human cadavers to which they were allocated. 
Each medical student that sustains an accidental injury in the department of Human Anatomy is required to complete an "Accidental injury Report" form that includes these details:

1.Person injured, age and gender

2. Date and time of accidental injuries.

3. Type of accidental injuries mechanism, procedure during which injury occurred

4. Body site injured and recorded outcome.

The number of medical students enrolled in each course during each course was obtained retrospectively from the records of the Human Anatomy Department J.M. Vargas Medical School at Central University of Venezuela, over a four-year period (2009-2012).

\section{Results}

During period among 2009-2012 records of the Human Anatomy Department J.M. Vargas School of Medicine show that proportion of female/male students was $3 \cdot: 1$ and the average age of first year medical students was 17 years old (ROMERO, 2010; ROMERO, 2011).

Overall accidental injuries were recorded in all groups of medical students, 10 accidental injuries were recorded in 10 students during 4 years period in a total group of 835 first year medical students. During the period of this study 7 females' students and 3 male students had accidental injuries (Table 1).

Eight $(80 \%)$ of the documented accidental injuries were from a scalpel blade, five of them were self-inflected while the 3 others were accidental injuries from another student. Four of the scalpel cuts occurred while removing the scalpel blade and 2 others while mounting the blade. Six out of the 8 blade injuries were on the left index finger. One out of the 8 blade injuries was on the right annular finger and one blade injury was on the right thumb. Two medical students were injured through formalin fluids splash on the face (Figure 1).

Mounting and removing scalpel blades accounted for $80 \%$ of these accidental injuries. The total incidence of accidental injuries in this study was $1,19 \%, 10$ of 835 medical students among 2009 and 2012

No accidental injury was recorded among staff members of Human Anatomy Department at J.M. Vargas School of Medicine during the 4-year period.
There was not a statistically significant difference in accidental injuries rates among the groups of medical students. Medical Students of the first year with no prior dissecting experience had a mostly similar incidence of injury (see Figure 2 ).

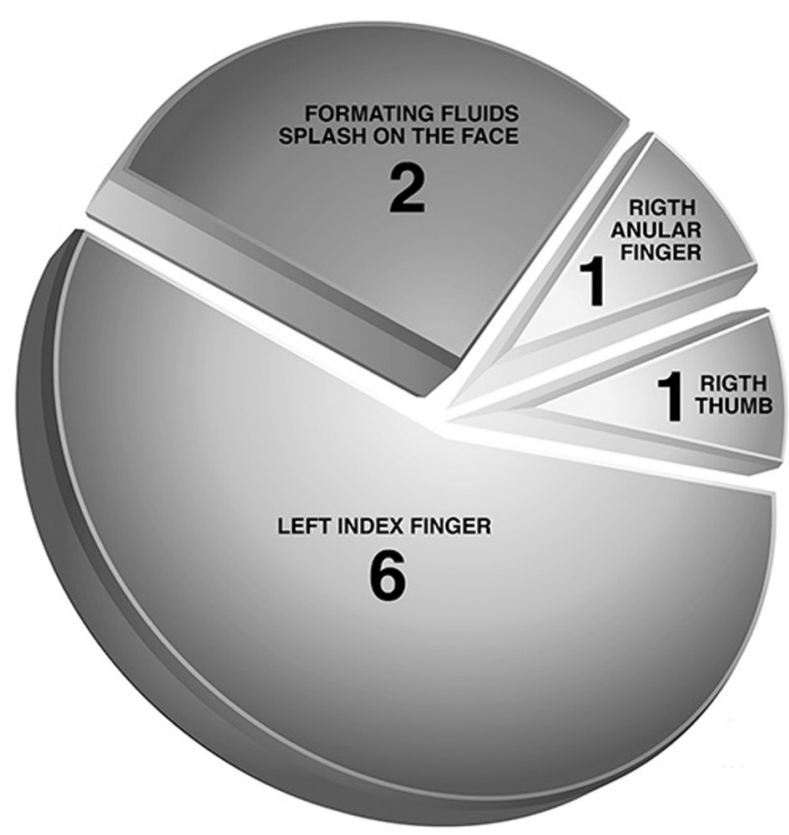

Figure 1. Body Sites Injured During Student Dissecting Room Accidental Injuries (2009/2012).

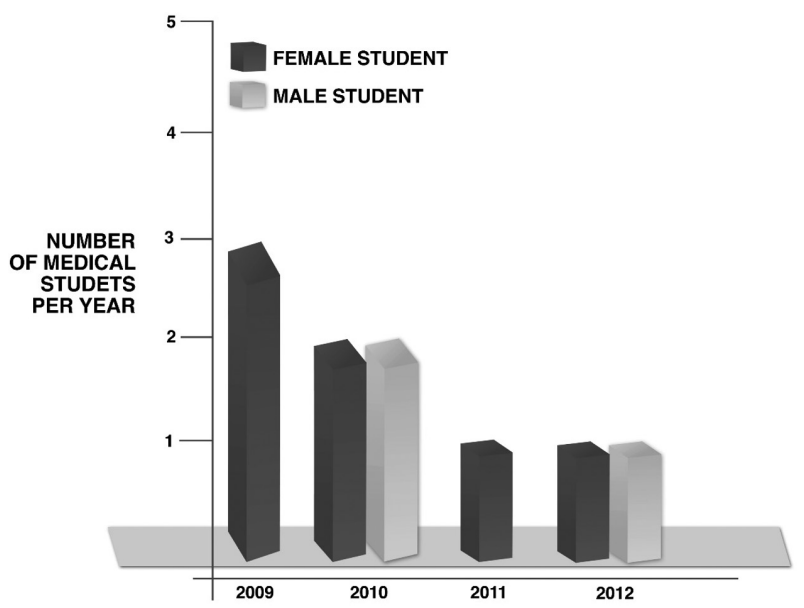

Figure 2. Accidental Injury Rates for Students Cohorts (2009/2012).

Table 1. Summary of accidental injuries in dissecting room.

\begin{tabular}{|c|c|c|c|c|c|}
\hline & 2009 & 2010 & 2011 & 2012 & TOTAL \\
\hline Average age & 17 & 17 & 18 & 17 & 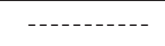 \\
\hline Gender & $3 \mathrm{~F}$ & $2 \mathrm{~F}+2 \mathrm{M}$ & $1 \mathrm{~F}$ & $1 F+1 M$ & $7 \mathrm{~F}+3 \mathrm{M}=10$ \\
\hline $\begin{array}{l}\text { Cuts from a scalp } \\
\text { blade }\end{array}$ & 2 & 3 & 1 & 2 & $8 / 10$ \\
\hline $\begin{array}{l}\text { Tissue splash on } \\
\text { the face }\end{array}$ & 1 & 1 & 0 & 0 & $2 / 10$ \\
\hline $\begin{array}{l}\text { Number of } \\
\text { students }\end{array}$ & 215 & 220 & 211 & 224 & 835 \\
\hline
\end{tabular}

F= Female Medical Students. $M=$ Male Medical Students. 


\section{Discussion and Conclusions}

In the past, accidental injuries in the dissecting room sometimes resulted in severe sepsis and sometimes death. Before the introduction of formaldehyde-based embalming techniques. Although during more than 50 years, there has been no published report of a medical student contracting a serious transmissible disease from dissection of a human cadaver (DUNN, 2005). The potential infection hazard from human cadavers is one of the risks of being medical students or being a member of a Human Anatomy Department. It is often claimed that fixatives are effective in inactivation of these agents. Unfortunately cadavers, even though they are fixed, may still pose infection hazards to those who handle them; therefore there is no room for complacency. Ten accidental injuries in the dissecting room were recorded in 7 female students, and in 3 male students during 2009-2012. The findings from this study suggest that medical students seldom injure themselves in the dissecting room.

In our Human Anatomy Department the incidence of accidental injuries in this study was one (19\%). However, when these accidental injuries occur, cuts from scalpel blades are the most common type of injury $(80 \%)$, either self-inflected or from a fellow student. Although all the accidental injuries documented in this study where minor, this should not dissuade us from considering preventive strategies. Since the majority of accidental injuries were from scalpel blades, medical students need to be frequently reminded about safety when handing these. This includes avoiding force when cutting with a scalpel, care when moving the instrument away from the area of dissection, and extra care if an assistant is retracting tissues. Sharp instruments should not be passed between students from hand to hand (WATT, PATKIN, SINNOTT et al., 2008). However, some scalpel blade injuries may be expected such as when the scalpel handle becomes greasy and slippery from the dissection of subcutaneous fat. Six out of 8 scalpel blade injuries occurred while removing or mounting the blade indicating that medical students must be shown a safe way of performing this using scalpel blade.

Preventive strategies such as double gloving and using dispensable scalpels may be useful options. This highlights scalpel handling and blade replacement as areas where preventive strategies and education on handling could be important in relation to decreasing future injury rates (WATT, PATKIN, SINNOTT et al., 2010; NAGHAVI and SANATI, 2009).

In order to prevent splash injuries through formalin fluids on the face or on eyes we need consensus to use protective eyewear. There was no record of foot accidental injuries from scalpels maybe because medical students use closed footwear.

Similarly in this study, there were no accidental injuries from incorrect use of sharps disposal bins and there were no documented accidental injuries from the use of scissors, even though pointed straight scissors are part of the standard dissecting kit for our students. The numbers of medical students being accidentally injured by other students were relative low, suggesting that the density of medical students gathered around the dissector was not a contributor to accidental injury in our dissecting environment. The goal of this study was to record the number and type of accidental injuries in the dissecting room per year during 2009-2012 and provides a view of the risks involved in the teaching practice in a dissection room at a Human Anatomy Department in Venezuela. The results of this study confirm those of previously published studies. (CORNWALL and STRINGER, 2008; CORNWALL, DAVIES and LEES, 2013; ROMERO, 2011).

This study has some limitations, describe the accidental injury risk to medical students from cadaver dissection data from 2009-2012 at one medical school. It is a retrospective study and some accidental injuries may not been recorded. Those that were recorded often lacked sufficient detail to enable a more in depth analysis of the specific mechanism of injury. The short period in which the study was performed is a limitation regarding the possibility of adverse outcomes later in time.

This study does not address "biological "risk from infectious agents or embalming fluids within dissecting room, although there have been not known instances of these among our medical students. Whilst common embalming chemicals are capable of killing most microorganisms, variable penetration of the tissues and partial inactivation by proteins may no achieve complete disinfection of the cadaver. Furthermore, none of these embalming agents is effective against prions (DEMIRYUREK, BAYRAMONG and USTACELEBI, 2002).

A new study would be interesting to compare the results of this study with those of advanced medical students to check if the most practical training is involved in the production of accidental injuries at the dissecting room.

It is important that all accidental injuries in the dissecting room are recorded to develop strategies to reduce risk and to protect medical students.

Staff of Human Anatomy Departments must stay up to date on the most current literature in the field to help ensure the safety of all medical students at the dissecting room under their supervision.

\section{Acknowledgements:}

The author thanks all medical students that participated in this study.

\section{References}

ARRÁEZ-AYBAR, LA., SÁNCHEZ-MONTESINOS, I., MIRAPEIX, RM., MOMPEO-CORREDERA, B. and SAÑUDO-TEJERO, JR.Relevance of human anatomy in daily clinical practice. Annals of Anatomy - Anatomischer Anzeiger, 2010, vol. 192, n. 6, p. 341-348.

BROWN, P., GIBBS JUNIOR, CJ., GAJDUSEK, DC., CATHALA, F. and LABAUGE, R. Transmission of Creutzfeldt-Jakob disease from formalin-fixed, paraffin-embedded human brain tissue. The New England Journal of Medicine, 1986, December 18, vol. 315, n. 25, p. 1614-1615. http://dx.doi.org/10.1056/NEJM198612183152517. PMid:3537790

CORNWALL, J. and STRINGER, MD. Physical injuries in the dissecting room. Clinical Anatomy, 2008, January, vol. 21, n. 1, p. 82-85. http://dx.doi.org/10.1002/ca.20566. PMid:18058901.

CORNWALL, J., DAVIES, TM. and LEES, D. Student injuries in the dissecting room. Anatomical Sciences Education, 2013, NovemberDecember, vol. 6, n. 6, p. 404-409. http://dx.doi.org/10.1002/ ase.1363. PMid:23536433.

DEMIRYUREK, D., BAYRAMONG, A. and USTACELEBI E. Infective agents in fixed human cadavers: a brief review and suggested guidelines. Anatomical Record (Part B: The New Anatomist), 2002, vol. 269, n. 4 , p. 104-197. 
DUNN, PM. Ignac Semmelweis (1818-1865) of Budapest and the prevention of puerperal fever. Archive of Disease Childhood Fetal Neonatal, 2005, vol. 90, p. F345-F348.

ELIZONDO-OMAÑA, R., GUZMAN-LOPEZ, S. and GARCIA, M. Dissection as a teaching tool: past, present, and future. Anatomical Record (Part B: The New Anatomist), 2005. vol. 285, n. 1, p. 11-15

KORF, HW., WICHT, H., SNIPES, RL., TIMMERMANS, JP., PAULSEN, F., RUNE, G. and BAUMGART-VOGT, E. The dissection course - necessary and indispensable for teaching anatomy to medical students. Annals of Anatomy - Anatomischer Anzeiger, 2008, vol. 190, n. 1, p. 16-22. http://dx.doi.org/10.1016/j.aanat.2007.10.001. PMid:18342138.

LEMPP, HK. Perceptions of dissection by students in one medical school: beyond learning about anatomy. A qualitative study. Medical Education, 2005, March, vol. 39, n. 3, p. 318-325. http://dx.doi. org/10.1111/j.1365-2929.2005.02095.x. PMid:15733168.

NAGHAVI, S. and SANATI, K. Accidental blood and body fluid exposure among doctors. Occupational Medicine, 2009, vol. 59, n. 2, p. 101-106.

ROMERO, R. Anatomical dissection: a positive experience for Venezuelan first year medical students. International Journal of Morphology, 2010, vol. 28, n. 1, p. 213-217.
ROMERO, R. Dissecting room accidents in a Venezuelan medical school. Anatomy, 2011, Suppl 5, S59. [Poster PP-50]

SHOJA, MM., BENNINGER, B., AGUTTER, P., LOUKAS, M. and TUBBS, RS. A historical perspective: infection from cadaveric dissection from the 18th to 20th centuries. Clinical Anatomy, 2013, March, vol. 26, n. 2, p. 154-160. http://dx.doi.org/10.1002/ ca.22169. PMid:23037893.

TURNEY, BW. Anatomy in a modern medical curriculum. Annals of the Royal College of Surgeons of England, 2007, March, vol. 89, n. 2, p. 104-107. http://dx.doi.org/10.1308/003588407X168244. PMid:17346399.

WATT, AM., PATKIN, M., SINNOTT, MJ., BLACK, RJ. and MADDERN, GJ. Scalpel injuries in the operating theatre. British Medicine Journal, 2008, vol. 336, n. 7652, p. 1031.

WATT, AM., PATKIN, M., SINNOTT, MJ., BLACK, RJ. and MADDERN, GJ. Scalpel safety in the operative setting: a systematic review. Surgery, 2010, January, vol. 147, n. 1, p. 98-106. http:// dx.doi.org/10.1016/j.surg.2009.08.001. PMid:19828169.

Received November 5, 2013 Accepted July 8, 2015 